Machinskaya, I. V. (1952). J. gen. Chem., Moscow, 22, 1159. Cited in Chem. Abstr. 47, 6357.

Mead, J. A. R., Smith, J. N. \& Williams, R. T. (1958). Biochem. J. 68, 61 .

Parke, D. V. \& Williams, R. T. (1950). Biochem. J. 46, 236.

Parke, D. V. \& Williams, R. T. (1953). Biochem. J. 54, 231.

Torboli, A. (1937). Boll. Soc. ital. Biol. sper. 12, 368.

Treon, J. F., Crutchfield, W. E. jun. \& Kitzmiller, K. V. (1943). J. industr. Hyg. 25, 199.
Van Slyke, D. D., Plazin, J. \& Weisiger, J. R. (1951). J. biol. Chem. 191, 299.

Vogel, A. I. (1956). Practical Organic Chemistry, 3rd ed. p. 895. London: Longmans, Green and Co.

Weitzel, G. (1950). Hoppe-Seyl. Z. 285, 58.

Wilson, N. H. B. \& Read, J. (1935). J. chem. Soc. p. 1268

Winstein, S., Hess, H. V. \& Buckles, R. E. (1942). J. Amer. chem. Soc. 64, 2796.

\title{
Haemorrhage and Tissue Electrolytes
}

\author{
By E. M. WIDDOWSON AND D. A. T. SOUTHGATE \\ Medical Research Council Department of Experimental Medicine, University of Cambridge
}

(Received 13 June 1958)

A survey of the literature reveals considerable variability in the concentration of chloride in skeletal muscle. The variability has been both from one investigator to another and from one animal to another. Darrow, Harrison \& Taffel (1939), for example, analysed the muscle of four normal dogs and found the chloride concentration to vary from 18.9 to $22.8 \mathrm{~m}$-equiv./kg., and Nichols, Nichols, Weil \& Wallace (1953) obtained similar figures. Kerpel-Fronius (1937), however, found $12.7 \mathrm{~m}$-equiv. $/ \mathrm{kg}$. Most of the published figures for the skeletal muscle of rats, rabbits and cats have been of the order of 12-14 m-equiv./kg. (KerpelFronius, 1937; Darrow et al. 1939; Hines \& Knowlton, 1939; Manery \& Hastings, 1939; Lowry, Hastings, Hull \& Brown, 1942). The concentration of chloride in human muscle has generally been found to be as high as or higher than those given by Darrow et al. (1939) for dogs. Kerpel-Fronius (1937) found 16.9 and $18.6 \mathrm{~m}$-equiv. $/ \mathrm{kg}$. in samples from two men, Talso, Spafford \& Blaw (1953) 19.1, Wilson (1955) an average of $25 \cdot 6$, with a range from $19 \cdot 3$ to $38 \cdot 3$, Mudge \& Vislocky (1949) $27 \cdot 4,28 \cdot 1$ and 29.7 and Barnes, Gordon \& Cope (1957) an average of 23.1 with a range from 13.9 to $39.1 \mathrm{~m}$ equiv./kg. There has not been the same variability in the concentration of chloride in other tissues, but since chloride is generally considered to be outside the cells, and to give a fair measure of the extracellular-fluid volume of an adult muscle we began to consider why the chloride in muscle was so variable. Even taking into consideration the facts that some authors express their results on a fat-free basis, whereas others do not, and that some but not others rinse their samples and blot them to remove superficial blood, the variation still remained very great, and it was clear that there was some other cause of the variability. The fact that bleeding the animal might have something to do with it was brought home to us when we compared the chloride concentrations in the muscles of pigs which had been killed and bled at the slaughterhouse with those from pigs which had not been bled. The average for the former group was 13 m-equiv./kg., that for the latter $22 \mathrm{~m}$-equiv. $/ \mathrm{kg}$. It was decided to look into this matter further and to investigate the effect of bleeding on the chemical composition of skeletal muscle of the rat, the fowl, the pig and man. Since, moreover, we wished to know whether chloride could be used as a measure of the extracellular fluid in young animals it was decided to try the effect of bleeding and at the same time to compare the chloride and inulin spaces in the tissues of the newborn pig.

\section{EXPERIMENTAL}

\section{Animals and experiments}

Rats. Five adult black-and-white hooded rats weighing about $300 \mathrm{~g}$. were anaesthetized with ether and as much as possible of the adductor and quadriceps muscles were taken from the right thigh. Then each animal was killed by bleeding from the abdominal aorta, and when it was dead the same muscles were taken from the other thigh. The amount of blood that could be removed before the animal died was not more than 5-8 ml.

A muscle taken from a living body is quite different in appearance from one taken from the body after it is dead. It is bright pink, with blood oozing from the small capillaries, whereas there is no visible blood in an autopsy specimen. It was thought that this in itself might affect the composition quite apart from any differences due to the removal of blood from the animal. In order to control this point, five other similar rats were anaesthetized as before, muscle was removed from the right thighs, the animals were killed with an overdose of ether and muscle was taken from the other side.

Cockerels. A healthy Rhode Island cockerel aged 26 weeks, weighing $3.5 \mathrm{~kg}$., was killed by decapitation and the bird was exsanguinated by hanging it head downwards. 
A second similar bird was killed by an overdose of ether and was not bled. Samples of pectoral muscle were taken from each animal.

Pigs : effects of bleeding. The pigs came from the Department's colony. They were all healthy at death. They were descendants of a pure-bred Large White $\times$ Essex cross subsequently mated with pure-bred Large White boars.

Muscle was removed from the thighs of four pigs weighing about $200 \mathrm{~kg}$. which had been killed at the slaughterhouse and had had their throats cut immediately after they had been electrocuted. The corresponding muscle was also taken from two animals of the same weight and breed which had not been bled.

In one newborn pig, weighing $1.5 \mathrm{~kg}$., muscle was removed from one thigh under pentobarbitone sodium (Nembutal) anaesthesia. Then $20 \mathrm{ml}$. of blood was taken from the heart and the animal killed by injecting air into the heart. Muscle was then taken from the other thigh and the two samples were analysed at the same time. The liver and heart were also taken for analysis. This piglet was a litter mate of the one to which inulin was given (see below), and served as its control.

Pigs: comparisons of inulin and chloride. Two piglets born in the evening were left with the sow for $10 \mathrm{hr}$., then removed to metabolism cages and given no further food. A volume (5 ml.) of $10 \%$ inulin solution was administered by cardiac puncture to one piglet, and any urine passed subsequently was collected. Two hours later $1.5 \mathrm{ml}$. of the $10 \%$ inulin solution was given subcutaneously, and $2 \mathrm{ml}$. was given after another $3 \mathrm{hr}$. The piglet was anaesthetized with pentobarbitone sodium $8 \mathrm{hr}$. after the first injection: $20 \mathrm{ml}$. of blood was removed from the heart and the serum separated. The animal was then killed by injecting air into the heart, and thigh muscle, liver and heart were removed for analysis. The control piglet, which received no inulin, was treated as described above, and its blood serum was also separated.

The serum, skeletal muscle, heart and liver of the two animals were analysed for inulin in duplicate, side by side, and the value obtained for the control animal was deducted from the one obtained for the experimental animal and the difference taken to be the concentration of 'true inulin' in the organ.

Man. Muscle from four men who had died as a result of street accidents were available for this comparison. Two of the men had sustained severe haemorrhage as a result of the accident and two had not.

\section{Sampling and chemical methods}

The muscle was freed from fat and connective tissue as far as possible and cut finely with scissors. The livers of the two newborn piglets were homogenized without added water in a Waring Blendor. The whole of the piglets' hearts were also cut up by hand. Weighed samples of the fresh material were dried to constant weight in silica crucibles at $100^{\circ}$, then ashed in a muffle furnace at $450^{\circ}$; the ash was extracted, first with conc. $\mathrm{HCl}$ and subsequently with $0.5 \mathrm{~N}$-acid as described by McCance, Widdowson \& Shackleton (1936), and the extract used for the determination of sodium, potassium and phosphorus.

At first some sodium and potassium determinations were made in a Beckman flame photometer on the acid extracts of the ash, but it was soon realized that the results obtained in this way were only $60-70 \%$ of the values obtained by chemical methods. Crismon (1948) and Bernstein (1952) also observed a reduction of emissions when working with acid extracts of tissue ashes, but they found complete agreement between chemical and flame-photometric methods after removal of phosphates. In the present investigation the Beckman flame photometer was used for the determination of sodium, but a measured amount of the acid extract was first evaporated to dryness and heated for $16-18 \mathrm{hr}$. at $100^{\circ}$ to remove all traces of acid, and taken up with water, shaken with solid $\mathrm{Ca}(\mathrm{OH})_{2}$ to remove phosphates and filtered. Results obtained in this way agreed well with those found by the more laborious chemical method with zinc uranyl acetate as precipitant. Potassium was determined chemically with sodium cobaltinitrite as described by McCance \& Shipp (1933). Phosphorus was estimated by King's (1932) method after heating a sample of the acid extract of the ash with a few drops of conc. $\mathrm{H}_{2} \mathrm{SO}_{4}$ to convert any pyrophosphate into orthophosphate. This method gave results in close agreement with those obtained by a wet-digestion method.

Chloride was estimated on duplicate samples of about $1 \mathrm{~g}$. of tissue by heating in a boiling-water bath with $5 \mathrm{ml}$. of $0.02 \mathrm{~N}-\mathrm{AgNO}_{3}$ and $5 \mathrm{ml}$. of conc. $\mathrm{HNO}_{3}$ and titrating the excess of $\mathrm{AgNO}_{3}$ with $0.02 \mathrm{~N}-\mathrm{KSCN}$ in the presence of $\mathrm{Fe}_{2}\left(\mathrm{SO}_{4}\right)_{3}$. Samples for nitrogen determination were weighed and transferred to Universal containers (Baird and Tatlock Ltd.), where they were covered with conc. $\mathrm{H}_{2} \mathrm{SO}_{4}$ and left to disintegrate. This took about a week at room temperature, but the process was hastened by heating in an oven at $100^{\circ}$ overnight. The mixture was made up to volume with water in a 50 or $100 \mathrm{ml}$. graduated flask and a portion ( 5 or $10 \mathrm{ml}$.) of the fine suspension taken for micro-Kjeldahl determination. The sample was digested with $2 \mathrm{ml}$. of conc. $\mathrm{H}_{2} \mathrm{SO}_{4}$, with copper selenite as catalyst. Fat was estimated on a sample of dried material by extraction with light petroleum.

Portions (about $2 \cdot 5$ g.) of muscle, liver and heart of the newborn piglet to which inulin had been given, and of its control, were covered with water and heated in a boilingwater bath for $10 \mathrm{~min}$. to destroy enzymic activity, and ground with sand. The mixture was transferred to a $50 \mathrm{ml}$. graduated cylinder and allowed to cool. Zinc sulphate solution ( $5 \mathrm{ml}$; $10 \%, \mathrm{w} / \mathrm{v}$ ) and $5 \mathrm{ml}$. of $0.5 \mathrm{~N}-\mathrm{NaOH}$ were added to precipitate the protein. The contents of the cylinder were made up to a known volume and filtered. A portion of the protein-free filtrate $(2 \mathrm{ml}$.) was extracted three times with redistilled butan-2-ol, the volumes of aqueous and non-aqueous phases being adjusted to give a ratio of 95:1 between non-aqueous and aqueous volumes after mixing. This process was carried out in order to remove the bulk of the extraneous substances giving a colour in the method used for the determination of fructose. The aqueous phase was then warmed to drive off excess of solvent and made to a known volume, and a portion taken for inulin determination. The estimation of fructose was made by the method of Cole as described by Bacon \& Bell (1948), but special precautions were taken to exclude light during colour development as exposure to bright light was found to reduce the intensity of the colour produced.

Inulin was determined in the serum after deproteinizing with $\mathrm{ZnSO}_{4}$ and $\mathrm{NaOH}$, and partitioning with butanol by the same procedure as that described for other tissues. Inulin in urine was determined directly on diluted urine. 
Chloride in serum was determined by Sendroy's (1937) technique, and sodium with the Beckman flame photometer. A portion $(0.2 \mathrm{ml}$.) of serum was added to $2 \mathrm{ml}$. of $10 \%$ trichloroacetic acid to precipitate the proteins; the mixture was centrifuged and $1 \mathrm{ml}$. of the supernatant fluid diluted to $10 \mathrm{ml}$. for the sodium determination.

\section{RESULTS}

Table 1 shows the effect of bleeding on the composition of the skeletal muscle of the rat, fowl, pig and man. The concentration of chloride was much lower in the muscles of the cockerel, pigs and men which had lost a great deal of blood before they died than in the muscles of those which had not. In pigs, for example, the difference was 9 m-equiv./ kg. and this could not have been due simply to a loss of blood serum from the muscle, for it would have meant that unbled animals' muscle contained over $90 \mathrm{ml}$. of serum or $150 \mathrm{ml}$. of blood $/ \mathrm{kg}$., which it clearly did not. It is evident that extracellular fluids had been withdrawn from the muscle into the circulation while the bleeding was going on, and this is confirmed by the figures for sodium in the pig and man. There was no such difference in the rat. This was no doubt partly because a much smaller proportion of the total blood volume was taken from the rats than from the cockerels or pigs, but in fact we found it impossible to remove more than about one-third of the blood volume of a rat by bleeding from the abdominal aorta or by decapitation. White \& Rolf $(1955,1956)$ do not seem to have had this difficulty, but in view of the rapidity with which rat's blood clots it seems as though the term 'exsanguination' as applied by various workers to rats may well not mean the same as it does in other species. It would be interesting to repeat this experiment with heparinized animals.

As might have been expected, the comparison of the composition of rat muscle obtained by biopsy with that of muscle obtained at autopsy without bleeding did not show any significant differences, and the results have therefore not been presented.

The concentrations of the cellular ions, potassium and phosphate, tended to be slightly higher in the muscle obtained after bleeding, but these may have been chance variations where the 'unbled' and 'bled' samples came from different animals or men. There were no consistent differences in the water or nitrogen. This is surprising, for a loss of extracellular fluid from the muscle must have resulted in a lower percentage of water in the tissue, and this anomalous result must have been due to individual variations and the small number of samples analysed.

The thigh muscle of the control newborn piglet contained $83.8 \%$ of water and $36 \mathrm{~m}$-equiv. of chloride/kg. before $20 \mathrm{ml}$. of blood was removed
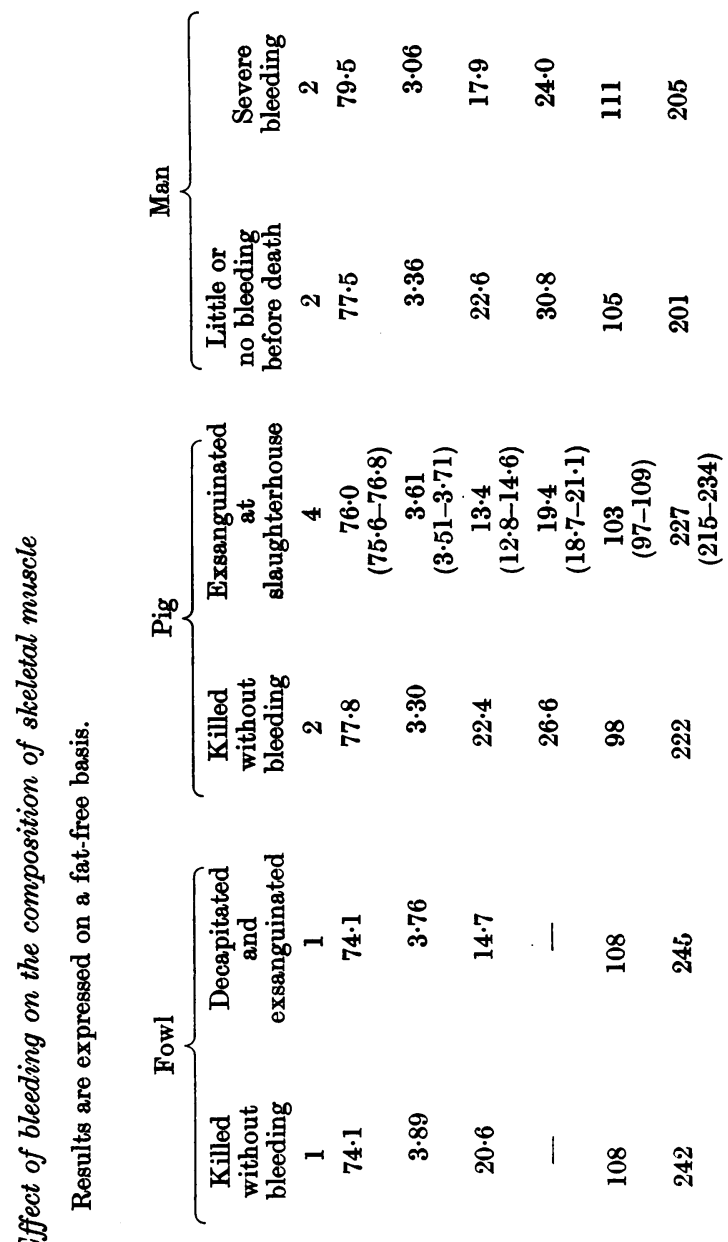

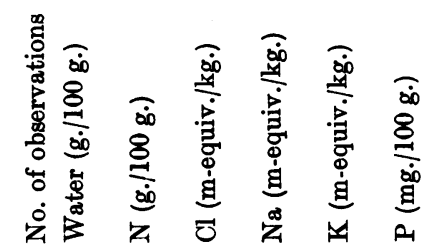


Table 2. Concentration of inulin, chloride and sodium in the serum and tissues of the experimental piglet, and the inulin, chloride and sodium 'spaces'

Water (g./100 g.)

Inulin (mg. $/ 100 \mathrm{~g}$.)

Cl (m-equiv./kg.)

$\mathrm{Na}$ (m-equiv./kg.)

Inulin 'space' (ml./100 g.)

Chloride 'space' (ml./100 g.)

Sodium 'space' (ml./100 g.)

$\begin{array}{cc}\text { Serum } & \text { Muscle } \\ - & 82 \cdot 8 \\ 17 \cdot 8 & 5 \cdot 06 \\ 103 & 34 \cdot 5 \\ 140 & 46 \cdot 5 \\ - & 28 \cdot 0 \\ - & 31 \cdot 0 \\ - & 33 \cdot 9\end{array}$

$\begin{array}{cc}\text { Heart } & \text { Liver } \\ 80 \cdot 9 & \mathbf{7 9 \cdot 0} \\ 5 \cdot 46 & 11 \cdot 8 \\ 41 \cdot 0 & \mathbf{3 6 \cdot 5} \\ - & \mathbf{4 5 \cdot 5} \\ \mathbf{3 0 \cdot 2} & 64 \cdot 9 \\ \mathbf{3 7 \cdot 1} & \mathbf{3 2 \cdot 8} \\ - & \mathbf{3 3 \cdot 5}\end{array}$

from the heart, and $82.8 \%$ of water and $33.5 \mathrm{~m}$ equiv. of chloride/kg. afterwards. It would appear that the removal of $20 \mathrm{ml}$. of blood, or about onesixth of the blood volume, from a newborn pig makes a measurable difference to the concentration of chloride in its muscle. Hence there may be a real difference between the response of rat muscle to haemorrhage and the response of the muscles of other animals, but work on more animals is needed to establish this point.

Table 2 shows the concentration of 'true inulin' and of chloride and sodium in the serum, skeletal muscle, heart and liver of the experimental piglet. The urine excreted by the experimental piglet contained $564 \mathrm{mg}$. of inulin, which was two-thirds of the dose injected. The concentration of inulin in the liver was over twice that in the skeletal muscle or heart, whereas the concentration of chloride was of the same order in all three tissues. Table 2 also shows the inulin 'space', chloride 'space' and the sodium 'space' in the same three tissues, calculated in the conventional way. The chloride space was a little higher than the inulin space in skeletal muscle but some such difference was to be expected from work on whole animals (Gaudino, Schwartz \& Levitt, 1948; Gamble \& Robertson, 1952). The same is true of the results for the heart, although the difference was a little greater. The sodium space corresponded closely to the chloride space. The inulin space in the liver, however, was twice that of the chloride space. This was due to the high concentration of inulin found there, and not to a low concentration of chloride, for the latter was similar to the value obtained on many other newborn piglets which were used for other investigations.

\section{DISCUSSION}

\section{Effect of haemorrhage}

The results of the present investigation indicate that bleeding materially reduces the concentration of chlorides in skeletal muscle, at any rate in some species. It seems important to recognize this, and it is in fact evident from the literature, for some authors have bled their animals to death, others have removed enough blood for analysis, whereas others have not removed any blood at all, and the figures for chlorides obtained by them all are in general agreement with the concept now put forward. The differences due to bleeding in man, the pig and the fowl, and probably also in the dog and cat, may be quantitatively much greater than differences due to fat, connective tissue or contaminating blood. If the chloride space is used only to calculate the composition of the intracellular compartment it probably will not make much difference to the conclusions reached whether or not the animals have been bled. It must, however, make a great difference to any calculation of the relationship of cell mass to extracellular water.

\section{Inulin and chloride spaces}

The present results confirm those of others that the chloride space in skeletal muscle is somewhat greater than the inulin space (Wilde, 1945; Cotlove, 1952; Mokotoff, Ross \& Leiter, 1952; Nichols et al. 1953), and it is clear that the newborn pig does not have large quantities of chloride in its muscle cells. White \& Rolf (1956) reported that the liver of the adult rat also 'holds up' inulin and they found that the same applied to skin and spleen. They suggested that macrophages in these three tissues actively ingest and concentrate inulin. This hold-up of inulin, probably within cells, clearly makes it useless as a guide to the extracellular space in these organs.

\section{SUMMARY}

1. The concentrations of chloride and of sodium in the skeletal muscle of man, the pig and the fowl are reduced by about one-third if severe bleeding takes place before death. The rat does not react in this way; this may be due partly to the fact that rats do not bleed as freely as other, larger animals, but there may be a further species difference.

2. The gross composition of the cells is probably little altered by bleeding.

3. The inulin 'space' in the skeletal and cardiac muscle of a newborn pig was a little less than the chloride 'space' but it was more than twice as large in the liver; inulin cannot be taken to measure the extracellular space in that organ. 
The results presented in this paper have been obtained in the course of several different investigations in which a number of people have been involved. We wish to thank them all, and particularly Professor R. A. McCance for his help with the presentation of the results. The method for the estimation of inulin in tissues was developed by $\mathrm{Dr}$ W. I. M. Holman, and the figures for the fowl were given us by Mr J. W. T. Dickerson.

\section{REFERENCES}

Bacon, J. S. D. \& Bell, D. J. (1948). Biochem. J. 42, 397.

Barnes, B. A., Gordon, E. B. \& Cope, O. (1957). J. clin. Invest. 36, 1239.

Bernstein, R. E. (1952). Biochim. biophys. Acta, 9, 576.

Cotlove, E. (1952). Fed. Proc. 11, 28.

Crismon, J. M. (1948). Fed. Proc. 7, 24.

Darrow, D. C., Harrison, H. E. \& Taffel, M. (1939). J. biol. Chem. 130, 487.

Gamble, J. L. jun. \& Robertson, J. S. (1952). Amer. J. Physiol. 171, 659.

Gaudino, M., Schwartz, J. L. \& Levitt, M. F. (1948). Proc. Soc. exp. Biol., N.Y., 68, 507.
Hines, H. M. \& Knowlton, G. C. (1939). Proc. Soc. exp. Biol., N.Y., 42, 133.

Kerpel-Fronius, E. (1937). Z. Kinderheilk. 58, 726.

King, E. J. (1932). Biochem. J. 26, 292.

Lowry, O. H., Hastings, A. B., Hull, T. Z. \& Brown, A. N. (1942). J. biol. Chem. 143, 271.

McCance, R. A. \& Shipp, H. L. (1933). Spec. Rep. Ser. med. Res. Coun., Lond., no. 187.

McCance, R. A., Widdowson, E. M. \& Shackleton, L. R. B. (1936). Spec. Rep. Ser. med. Res. Coun., Lond., no. 213.

Manery, J. F. \& Hastings, A. B. (1939). J. biol. Chem. 127, 657.

Mokotoff, R., Ross, G. \& Leiter, L. (1952). J. clin. Invest. 31, 291.

Mudge, G. H. \& Vislocky, K. (1949). J. clin. Invest. 28, 482.

Nichols, G. jun., Nichols, N., Weil, W. B. \& Wallace, W. M. (1953). J. clin. Invest. 32, 1299.

Sendroy, J. (1937). J. biol. Chem. 120, 405.

Talso, P. J., Spafford, N. \& Blaw, M. (1953). J. Lab. clin. Med. 41, 405.

White, H. L. \& Rolf, D. (1955). Amer. J. Physiol. 180, 287.

White, H. L. \& Rolf, D. (1956). Amer. J. Physiol. 185, 152.

Wilde, W. S. (1945). Amer. J. Physiol. 143, 666.

Wilson, A. O. (1955). Brit. J. Surg. 43, 71.

\title{
The Effect of Ghlorpromazine on the Respiratory Chain
}

\author{
CYTOCHROME OXIDASE
}

\author{
By M. J. R. DAWKINS,* J. D. JUDAH AND K. R. REES \\ Department of Morbid Anatomy, University College Hospital Medical School and Biochemistry Department, \\ University College London
}

(Received 17 September 1958)

The phenothiazine 'tranquillizer' chlorpromazine [10(3-dimethylaminopropyl) - 2 - chlorphenothiazine hydrochloride] has a powerful depressant action on the central nervous system. In view of the inhibitory effects of the barbiturates on electron transport (Ernster, 1956), we have investigated the effects of chlorpromazine on the respiratory chain. The work of Berger, Strecker \& Waelsch (1956) has shown that chlorpromazine inhibited the phosphorylation coupled to the oxidation of cytochrome $c$. This paper is concerned with a detailed analysis of this inhibition.

\section{METHODS}

Wistar albino rats fed on an unrestricted M.R.C. diet no. 41 (Bruce, 1950) were used throughout the investigation. Mitochondria were prepared from liver by the method of Schneider (1948) and from brain as described by Christie, Judah \& Rees (1953). Mitochondria were depleted of pyridine nucleotide by pre-incubation in $0.25 \mathrm{M}$-sucrose$0 \cdot 025$ M-sodium orthophosphate-HCl buffer, $\mathrm{pH} \mathrm{7.2,} \mathrm{for}$

* Stothert Research Fellow of the Royal Society.
$10 \mathrm{~min}$. at $30^{\circ}$ before use, as described by Hunter \& Ford (1955). The phosphorylation coupled to the oxidation of ferrocytochrome $c$ was studied with mitochondria suspended in $0.25 \mathrm{M}$-sucrose as described by Judah (1951) or suspended in $0.075 \mathrm{M}$-sucrose as described by Lehninger. ul Hassan \& Sudduth (1954). Phosphorylation coupled to the reduction of cytochrome $c$ by $L$-glutamate and $\beta$ hydroxybutyrate was studied by the method of Borgstrom, Sudduth \& Lehninger (1955). The reduction of cytochrome $c$ was followed spectrophotometrically with the Unicam SP. 500 spectrophotometer by measuring the increase in absorption at $550 \mathrm{~m} \mu$. Phosphorylation was measured by the method described by Nielsen \& Lehninger (1955).

Oxidative phosphorylation with oxygen as electron acceptor was studied as described by Judah (1951). The final concentrations of the components were: adenosine triphosphate (ATP), $1.7 \mathrm{~mm} ; \mathrm{MgSO}_{4}, 6.7 \mathrm{~mm} ; \mathrm{KCl}$, $25 \mathrm{~mm}$; sodium orthophosphate-HCl buffer, pH 7.2, $10 \mathrm{~mm}$; cytochrome $c, 10 \mu \mathrm{M}$; glucose, $30 \mathrm{~mm}$; purified yeast hexokinase added in $0.05 \mathrm{ml}$.; substrate $10 \mathrm{~mm}$; $\mathrm{NaF}, 13 \mathrm{~mm}$. Mitochondria were added in $0.25 \mathrm{M}$-sucrose as indicated in the text. Final volume was $3 \mathrm{ml}$. Incubation temperatures are indicated for each experiment. The gas phase was air.

Ethylenediaminetetra-acetate (EDTA) was added as indicated in all experiments with cytochrome oxidase in 